\title{
PENINGKATAN SISTEM PELAYANAN DENGAN PENERAPAN MODEL SISTEM INFORMASI MANAJEMEN SATU ATAP
}

\author{
Arfigo Yahya \\ Jurusan Sistem Informasi \\ Fakultas Sains dan Teknologi \\ Universitas Islam Negeri Sumatera Utara \\ Email : arfigoyahya06@gmail.com
}

\begin{abstract}
Abstrak
Untuk memenuhi kebutuhan akan data yang bagus dan untuk membantu interaksi dinamis yang cakap dan aktif di dalam Pemerintahan Teritorial baik pada tingkat Umum dan Rezim / Kota, penting untuk membangun dan mengembangkan Kerangka Data Eksekutif Terpadu untuk membantu kebutuhan data kapasitas fundamental dan pendukung untuk Pemerintah Provinsi juga di semua tingkatan sesuai dengan lapisan data yang telah ditetapkan. Secara khusus, kerangka kerja ini akan menjunjung tinggi pelaksanaan administrasi di wilayah setempat yang memerlukan izin operasi, izin bangunan, hewan, dan sebagainya. Administrasi ini harus diberikan idealnya dan sesekali harus ada peningkatan unit bantuan yang ada dengan didukung oleh kerangka data yang memuaskan. Oleh karena itu, otoritas publik dari Peraturan Ogan Komering Ilir sedang mengembangkan Kerangka Data Dewan Satu Atap saat ini sehingga dapat menegakkan administrasi yang lebih ideal di daerah setempat.
\end{abstract}

\section{Kata Kunci : Sistem Informasi Manajemen Satu Atap}

\section{A. PENDAhuluan}

Di masa desentralisasi dan pemerintahan sendiri provinsi, perbaikan moneter merupakan salah satu proyek penting dan vital dalam upaya membangun kembali perekonomian masyarakat. Kemajuan keuangan provinsi tidak hanya dimaksudkan untuk memperkuat fleksibilitas keuangan negara itu sendiri, tetapi juga mengakui perubahan keuangan yang wajar. Fleksibilitas moneter teritorial bergantung pada potensi keuangan di sekitarnya untuk diawasi secara tepat dan efektif. Sejak pelaksanaan strategi desentralisasi, interaksi dinamis untuk pendekatan moneter telah dialihkan ke daerah, mengingat istilah otorisasi, yang sebagian besar adalah spesialis provinsi selain yang penting dan dalam skala publik. Para ahli provinsi menemukan cara cepat yang mendasar untuk meningkatkan pembangunan keuangan dengan menelusuri pendekatan yang paling ideal untuk menarik usaha. Pengenalan Permendagri No. 24 Tahun 2006 tentang Tata Tertib Penyelenggaraan Pemerintahan Koordinasi Satu Pintu merupakan salah satu instrumen untuk membangun lingkungan spekulasi yang berguna bagi usaha dan usaha untuk lebih meningkatkan dan menggairahkan perekonomian individu dan perekonomian provinsi.

Pemerintah lingkungan mulai memahami pentingnya meningkatkan administrasi perizinan usaha untuk organisasi yang bekerja di daerah mereka, terutama untuk usaha kecil dan menengah (UKM), yang tersebar di berbagai kabupaten. Pemilik organisasi memerlukan izin untuk beroperasi jika mereka ingin mengembangkan bisnisnya. Memiliki izin untuk beroperasi akan membantu membentuk kepribadian perusahaan, dan kemudian bekerja dengan akses bagi pemilik organisasi untuk memperluas pasar atau mengelola yayasan keuangan. Meskipun demikian, jumlah organisasi yang terdaftar secara resmi masih sedikit 
karena tingginya biaya perizinan dan kebutuhan regulasi yang menindas. Pemerintah terdekat merasakan keuntungan dari otorisasi bisnis. Dari perspektif mereka, informasi tentang jumlah organisasi terdekat akan mengamankan organisasi-organisasi ini dan secara bersamaan memungkinkan otoritas publik untuk menyusun undang-undang, strategi, dan proyek baru yang diidentifikasi dengan dunia bisnis.

Untuk mencapai dukungan publik yang luar biasa dari area lokal, Rezim OKI telah mengembangkan ide administrasi satu atap yang dimilikinya. Gagasan One-Stop Kerangka Data Eksekutif dalam Ogan Komering Ilir Rule (OKI) digarisbawahi pada "administrasi", sedangkan TIK (terkomputerisasi) ditempatkan sebagai bagian pendukung (penunjang) dan agen yang memberdayakan. Keinginan, kebutuhan dan kapasitas daerah setempat sebagai klien atau klien secara konsisten menjadi pemicu dan pendorong untuk meningkatkan ukuran kerja dan mengubah jenis administrasi TIK yang dibutuhkan oleh pemerintah Rezim OKI dimana gagasan tersebut akan mendorong administrasi yang hebat (administrasi yang hebat).

Aturan realisasi klien secara konsisten menjadi aturan pemerintah Rezim OKI dalam menawarkan jenis bantuan kepada daerah setempat. Keragaman masyarakat mempengaruhi kerinduan, tingkat kebutuhan dan kapasitas mereka, namun masyarakat dimanapun memiliki harapan dan keinginan yang sama terhadap administrasi publik. Misalnya, semua orang mengharapkan layanan yang sederhana, dapat diandalkan dan dapat diandalkan. Upaya yang tak terhitung jumlahnya telah dilakukan oleh pemerintah Rezim OKI dengan tujuan akhir untuk memuaskan kerinduan daerah setempat dengan berusaha memberikan administrasi yang sederhana, solid dan berkualitas.

\section{B. TARGET LAYANAN MASYARAKAT}

- Sesuai dengan tujuan dalam catatan strategi terobosan Perbaikan Pemerintah Area OKI bahwa hingga tahun 2009 pelaksanaan TIK untuk administrasi publik dimaksudkan untuk nol tambahan pada administrasi perizinan dan administrasi yang mengomel. Dalam pemanfaatan inovasi data, penting untuk difokuskan pada beberapa hal, antara lain:

- Kelompok masyarakat (mitra) secara konsisten memiliki permintaan, yang biasanya mengarah pada kemampuan beradaptasi bagi mereka 24 jam per hari untuk mendapatkan administrasi dari otoritas publik.

- Individu perlu secara terbuka berasosiasi dengan otoritas publik dari area favorit mereka, seperti rumah, tempat kerja, fokus bisnis, atau dari kendaraan transportasi. Kelompok masyarakat secara konsisten percaya bahwa saluran masuk yang digunakan dapat berbeda, bergantung pada perangkat yang mereka miliki.

- Tatanan sosial biasa biasanya membutuhkan item dan administrasi pemerintah untuk diakses melalui kantor seperti telepon rumah dan internet, sementara yang lebih sekarang akan membutuhkan kantor untuk ATP, PDA, PC, dll. 
- Untuk mencapai tujuan ini, salah satu cara yang dilakukan oleh pemerintah Ogan Komering Ilir (OKI) adalah dengan membina kantor TIK mereka harus memiliki pilihan untuk menawarkan peningkatan bantuan yang lebih baik ke daerah setempat. Upaya yang akan dilakukan adalah meningkatkan administrasi ke daerah, khususnya dalam bidang pengurusan hibah yang dibutuhkan daerah seperti SIUP, SITU, SIUJK, IMB, TDI, TDP, TDG, IUP, IUPP, SPIT, SIUP, IUP dan HU, IPA. selanjutnya, TO, IPR, IMSS, IMLPK

\section{METODOLOGI PENGEMBANGAN SIMTAP}

Strategi yang digunakan dalam pergantian event dan perencanaan aplikasi SIMTAP Territorial menggunakan prosedur Framework Improvement Life Cycle, selanjutnya adalah penyusunan tahapan interaksi:

\section{Kerangka Studi}

Dapatkan data tentang pengukuran dalam asosiasi, bingkai laporan yang diperlukan, dan kumpulan data yang ada.

\section{Tampilan dan Perancangan Kerangka}

Tentukan prasyarat untuk semua komponen kerangka dan kemudian cari tahu mana yang digunakan untuk kerangka

\section{Pemeriksaan Kerangka Prasyarat}

Untuk mengetahui sejauh mana kerangka kerja, ciri prasyarat kerangka kerja dan batasan kerangka kerja secara mendalam

\section{Rencana / Kerangka Rencana}

Cara menerapkan strategi dan standar yang berbeda untuk menggambarkan secara menyeluruh perangkat, interaksi atau kerangka sehingga dapat diterima dengan baik dalam struktur yang sebenarnya

\section{Buat Kode}

Cara untuk membuat interpretasi rencana kerangka kerja ke dalam bahasa pemrograman yang telah ditentukan sebelumnya.

\section{Pengujian Kerangka}

Menilai penataan produk yang terdiri dari ihwal kebutuhan, gambaran rencana, dan program selanjutnya

7. Eksekusi Kerangka / Eksekusi KerangkaF 


\section{GAMBARAN UMUM SISTEM INFORMASI SATU ATAP YANG SEDANG BERJALAN}

SIMTAP secara keseluruhan adalah kerangka kerja terkoordinasi, yang terdiri dari Kerangka Peralatan dan Kerangka Pemrograman PC. Kerangka peralatan yang digunakan dalam SIMTAP adalah kerangka kerja PC berbasis PC dan semua perangkat kerasnya, yang digabungkan ke dalam Kerangka Kerja Organisasi Terdekat (LAN = Lingkungan) dengan kerangka kerja jaringan Microsoft Windows NT. Kerangka kerja pemrograman SIMTAP adalah program aplikasi yang berkembang tidak biasa yang berjalan di bawah kerangka kerja Microsoft Windows. Kerangka ini dibuat dengan

Pertimbangkan bagian kenyamanan oleh klien tanpa mengurangi nilai selera dalam hiburan layar. Aplikasi SIMTAP dikendalikan melalui Kerangka Menu yang lugas, untuk mengharapkan potensi kesalahan dalam pemanfaatannya dan direncanakan sebagai kerangka kerja cerdas, di mana klien dapat berbicara langsung dengan PC untuk mendapatkan informasi staf dan reaksi oleh PC diberikan sebagai etalase mengingat info yang dimasukkan.

Dengan kerangka kerja cerdas ini dipercaya bahwa klien akan mendapatkan data sesuai kebutuhan mereka dalam waktu yang paling terbatas. Hasil selanjutnya dari data ini dapat dikumpulkan sebagai laporan dan desain, dimana jenis laporan selanjutnya dapat ditampilkan pada media layar atau pada media cetak printer. Dalam menawarkan jenis bantuan kepada masyarakat secara umum, SIMTAP merupakan kerangka kerja administrasi satu pintu yang mencakup 9 administrasi perizinan yang terdiri dari: penyelenggara IMB, penyelenggara SIUJK, penyelenggara izin penyelenggaraan hewan (IUP), penyelenggara administrasi penyuluhan hewan (IUPP) pertukaran. Surat Izin Penyelenggaraan (SIUP). ), Administrasi Hibah Area Bisnis (SITU), Administrasi Pendaftaran Industri Kecil (TDI), Administrasi Pengesahan Pendaftaran Organisasi (TDP), Administrasi Perjanjian Pendaftaran Ruang Persediaan (TDG). Selain 9 administrasi di atas, SIMTAP juga menyediakan kantor kas, di mana semua langkah pembayaran yang diselesaikan di Kantor Perizinan dan Spekulasi Peraturan OKI disatukan. Untuk otoritas Pemerintah Teritorial OKI: Pejabat, Pejabat yang Ditunjuk, Sekretaris Provinsi, Kepala Administrasi, dapat dengan lugas menyaring derajat administrasi dari otoritas di lapangan melalui situs data yang telah diatur sebelumnya. Melalui SIMTAP ini, Anda dapat segera menyaring jumlah pendaftar untuk setiap bantuan, situasi dengan setiap permintaan untuk setiap bantuan, waktu puncak untuk setiap aplikasi, dan juga pendapatan yang akan datang.

\section{E. KONDISI PELAYANAN SISTEM SATU ATAP YANG SEDANG BERJALAN}

Kondisi pelayanan yang terjadi saat ini sudah menerapkan sistem loket dimana pelayanan kepada masyarakat terpusat pada satu gedung. Masyarakat yang membutuhkan pelayanan dapat mengurus surat izin yang diperlukan pada layanan loket yang telah disediakan. Sistem pelayanan satu atap yang telah ada menerapkan sistem pelayanan loket dimana Badan Perizinan dan Penanaman Modal sebagai tempat pelayanan SIMTAP menyediakan empat buah loket yang memiliki beberapa fungsi :

- Loket I (Pendaftaran) yang memiliki tugas untuk meneliti kelengkapan persyaratan 
administrasi pemohon pelayanan, mengembalikan berkas pemohon yang tidak lengkap, memberikan tanda bukti penerimaan berkas dan membuat laporan pelaksanaan tugas kepada koordinator melalui sekretaris.

- Loket II (Pembayaran) yang memiliki tugas menetapkan jumlah retribusi pemohon, menerima pembayaran, melaksanakan pengesahan pembayaran, melaksanakan pembukuan administrasi keuangan, menyetor penerimaan pembayaran ke Kas Daerah/Kas Negara, membuat laporan keuangan harian, bulanan maupun tahunan dan membuat laporan pelaksanaan tugas kepada koordinator melalui sekretaris.

- Loket III (Penyerahan / Pengambilan), mempunyai tugas untuk menyerahkan berkas yang sudah diproses dan ditanda tangani oleh pejabat yang berwenang kepada 
pemohon, membuat bukti serah terima berkas, mencatat arus waktu penyelesaian perizinan dan membuat laporan kepada koordinator .

- Loket IV (Informasi), mempunyai tugas untuk melayani informasi yang terkait dengan pelayanan umum di Kanot Badan Perizinan dan Penanaman Modal Kapupaten Ogan Komering Ilir.

Setiap loket dilayanani oleh satu orang petugas loket untuk setiap loket pelayanan. Loket pelayanan ini berfungsi sebagi front office untuk setiap pemohon yang ingin mengurus perizinan yang ia butuhkan.

Orang-orang pada umumnya / kandidat yang perlu menjadi dalang lisensi yang mereka butuhkan mendaftar dan menunjukkan dokumen-dokumen di loket pendaftaran yang telah diberikan. Setelah semua laporan selesai, kandidat dapat menangani cicilan sesuai pengaturan yang relevan. Total dokumen akan disiapkan dan disetujui dan diperiksa silang dengan kantor-kantor penting. Setelah mendapatkan dukungan dari organisasi terkait, surat hibah dapat dicetak dan kandidat dapat memulihkan hasil di segmen akomodasi dokumen.

\section{F. Status APLIKASI Kerangka Data Rooftop SATU SAAT INI}

Aplikasi One-Stop The Executive Data Framework (SIMTAP) yang saat ini berjalan mencakup 9 administrasi yang terdiri dari:

\section{Modul Administrasi IMB}

\section{Modul Administrasi SIUJK}

3. Surat Izin Penyelenggaraan Modul Administrasi (SIUP)

\section{Modul Administrasi Lisensi Tempat Bisnis (SITU)}

5.Modul Administrasi Perjanjian Pendaftaran Industri Kecil (TDI)

6. Modul Administrasi Pernyataan Pendaftaran Pendaftaran Perusahaan (TDP)

7. Modul Administrasi Pendaftaran Ruang Persediaan (TDG)

8. Izin Penyelenggaraan Hewan Domestik Modul Administrasi (IUP)

9. Modul Administrasi Penanaman Izin Perluasan Penyelenggaraan (IUPP)

Setiap modul aplikasi dipisahkan menjadi beberapa cakupan bantuan pusat administrasi yang belum dikaitkan dengan pekerja soliter. Model aplikasi yang dibuat merupakan aplikasi soliter client yang memanfaatkan kumpulan data Microsoft Access 2000 dengan aplikasi pemrograman Visual Essential untuk rancangan antarmuka framework. Kehadiran pekerja di Tempat Kerja Organisasi Perizinan dan Spekulasi tidak digunakan seperti yang diharapkan dan aplikasi hanya dapat mencetak dukungan otorisasi pada PC tertentu. 


\section{F. HASIL SURVEY}

Dari kerangka tinjauan umum yang dipimpin, dapat disimpulkan bahwa administrasi Kerangka Data Dewan Satu Atap (SIMTAP) di Tempat Kerja Unit Organisasi Perizinan dan Spekulasi diisolasi menjadi dua fokus bantuan mendasar, yaitu kantor depan dan pusat administrasi.

a. Sebuah. Front office adalah bagian awal administrasi yang secara langsung mengkomunikasikan / menawarkan jenis bantuan kepada individu yang membutuhkan lisensi yang mereka butuhkan.

b. Pusat Administrasi adalah unit pendamping yang berkapasitas mendata dokumen bantuan yang dibutuhkan oleh calon, Kantor Perijinan dan Ventura saat ini memiliki informasi penyiapan aplikasi yang mampu mencatat dan mencetak izin yang dibutuhkan oleh calon. Aplikasi ini diperkenalkan pada lima PC pelanggan. Setiap PC pelanggan digunakan untuk membuat lisensi terpisah dari setiap organisasi yang diidentifikasi dengan administrasi yang diberikan.

- Financial Area, bertanggung jawab untuk membuat Business Spot Grant (SITU)

- Government Segment, bertanggung jawab melayani pengembangan Structure Development Grant (IMB)

- Peningkatan Area Organisasi, bertanggung jawab untuk pembuatan Izin Administrasi Pembangunan (IUJK), Perjanjian Pendaftaran Mekanis (TDI), Deklarasi Pendaftaran Organisasi (TDP) dan Pengesahan Daftar Gudang (TDG)

- Divisi Kegiatan, mendapat tugas membuat Surat Izin Usaha Pertukaran (SIUP)

- Divisi Budidaya Hewan, bertanggung jawab dalam pembuatan Izin Usaha Budidaya Hewan (IUP) dan Izin Penyuluhan Hewan Domestikasi Penyelenggaraan (IUPP)

1. Bagaimanapun, dalam kerangka administrasi satu pintu saat ini, ditemukan beberapa kekurangan yang menyebabkan bantuan yang diberikan kurang ideal, yang dapat ditutup sebagai berikut:

2. Luasnya pemanfaatan di pusat administrasi hanya mencakup pencetakan hibah wajib (print out) namun tidak mencakup kebutuhan yang berbeda, misalnya pengecekan dokumen, angsuran, data dan laporan yang dibutuhkan oleh pengurus (Kepada Badan Otorisasi dan Spekulasi) dan kantor terkait. Bukan kantor depan sebagai pelopor administrasi, administrasi

3. yang dilakukan di front office masih bersifat manual, khususnya untuk bagian akun, sehingga menyulitkan siklus akuntansi dan perincian ke administrasi untuk situasi ini Puncak Kantor Perizinan dan Spekulasi Rejim Ogan Komering Ilir.

4. Kekurangan aplikasi pendukung administrasi (Pimpinan Kantor Perizinan dan Ventura) 
sebagai metode pemeriksaan dan pengendalian administrasi telah selesai. Kesulitan bagi pihak administrasi dalam mendapatkan laporan-laporan yang diperlukan, hal ini dikarenakan setiap divisi/unit administrasi perkantoran dan pusat administrasi bergaya tekstual belum dilengkapi dengan kerangka aplikasi yang terintegrasi/konsentrasi, sehingga sulit untuk memberikan laporan yang diperlukan dari setiap unit.

5. Kelompok masyarakat belum memiliki pilihan untuk mendapatkan data dengan cepat untuk mendapatkan pilihan untuk menemukan kebutuhan yang diperlukan dalam mempersiapkan perizinan yang mereka butuhkan. Misalnya, untuk mengumpulkan catatan lamaran untuk mendapatkan hibah, masyarakat umum harus datang langsung ke Tempat Kerja Organisasi Perizinan dan Spekulasi hanya untuk mengumpulkan dokumen lamaran yang mereka butuhkan. Ini menghasilkan kesan yang lebih negatif dan kurang layak untuk diberikan oleh pemerintah. Terlebih lagi, individu yang mengalami masalah mengetahui situasi dengan catatan / laporan yang telah ditangani, untuk mendapatkan jawaban mengenai hal ini, orang-orang pada umumnya harus pergi ke Tempat Kerja Organisasi Pengotorisasi dan Spekulasi atau bertanya langsung ke kantor-kantor penting di berkaitan dengan situasi dengan arsip mereka.

\section{G. KEBUTUHAN FUNGSIONAL}

Berdasarkan hasil survey awal sistem yang telah dilakukan dan kendala yang ditemui dilapangan maka dapat diketahui kebutuhan fungsional sistem yaitu perlunya dilakukan pengembangan terhadap Sistem Informasi Manajemen Satu Atap yang ada. Konsep pengembangan SIMTAP yang dapat dilakukan terfokus pada 3 jenis kegiatan pembangunan aplikasi yang terdiri dari :

1. Pembangunan Aplikasi Front Office

Aplikasi ini terdiri dari beberapa modul sistem yang akan digunakan di masing-masing loket pelayanan, yang terdiri dari :

- Modul Pendafataran

Merupakan modul aplikasi yang akan digunakan dibagian pendataan. Modul aplikasi ini merupakan modul awal pelayanan sistem dimana pada modul pendafataran ini setiap berkas surat izin yang masuk akan di data dan akan dilakukan pendataan terhadap syarat-syarat kelengkapan berkas secara keseluruhan. Pada modul ini akan me-record status awal dokumen/berkas danwaktu pelayanan.

- Modul Pembayaran

Pada modul aplikasi ini akan digunakan di bagian pembayaran. Modul ini akan mendata setiap kegiatan pembayaran yang dilakukan dan akan menghasilkan laporan rekapitulasi pembayaran yang akan digunakan sebagai laporan kepimpinan. 
- Modul Penyerahan Berkas

Modul aplikasi ini akan digunakan pada bagian penyerahan berkas yang berfungsi untuk mendata surat-surat yang telah selesai berikut waktu pengambilan dan perubahan status dokumen.

- Modul Informasi

Modul ini akan memberikan informasi tentang syarat yang dibutuhkan untuk pengurusan surat izin yang diperlukan.

\section{Pengembangan Situs Data}

Situs ini dimanfaatkan sebagai mekanisme pendataan bagi masyarakat pada umumnya dan pihak pemerintahan terkait. Situs ini akan dikaitkan dengan pekerja SIMTAP saat ini di mana informasi yang diperkenalkan oleh situs data diambil langsung dari kumpulan data SIMTAP saat ini. Kumpulan data SIMTAP akan diubah dan dibingkai sebagai kumpulan data lain yang nantinya akan digunakan oleh situs data sebagai metode data bagi masyarakat umum untuk mengetahui situasi dengan arsip mereka dan sebagai kendaraan kontrol bagi pengurus, baik SIMTAP. penyelenggara dan eksekutif dari dinas terkait untuk mengetahui kuantitas laporan yang ada dan ukuran pendapatan yang diperoleh. Dengan rencana situs ini, setiap pertemuan dapat menawarkan jenis bantuan yang langsung kepada administrasi yang diberikan.

\section{Perbaikan Media Data Pengurus}

Aplikasi pendukung untuk dewan untuk mengontrol administrasi yang ada untuk membantu dinamika. Aplikasi menyajikan laporan-laporan yang dibutuhkan oleh penyelenggara UPT / SIMTAP.

\section{KEBUTUHAN NON FUNGSIONAL}

Kebutuhan Non-Praktis di sini adalah persyaratan yang diidentifikasi dengan penggunaan, kecepatan akses kerangka yang dibuat, ketergantungan administrasi dan keamanan informasi yang diklaim oleh kerangka yang akan dibuat.

\section{Kegunaan}

Dalam menggunakan SIMTAP, klien tidak terlalu sulit untuk mempertimbangkan untuk menggunakan SIMTAP ini secara langsung, karena SIMTAP memiliki UI yang menarik yang tidak sulit untuk dipelajari dan memiliki petunjuk penggunaan yang jelas.

\section{Kecepatan Akses}

Dalam pelaksanaannya, salah satu masalah adalah akses terbatas ke data. Dengan cara ini SIMTAP yang dibuat akan memiliki kecepatan dalam memasukkan data pada saat data tersebut akan digunakan. Selain itu, akses ke pekerja yang digunakan juga tidak akan memakan waktu lama, sehingga klien tidak perlu ragu untuk bergaul dengan pekerja tersebut.

\section{Administrasi Ketergantungan}

Dalam memanfaatkan SIMTAP ini, klien dapat memanfaatkan semua kapasitas yang terdapat dalam SIMTAP, yang tersirat di sini adalah bahwa semua kapasitas yang ada dapat dimanfaatkan oleh klien. Selain itu, hubungan dengan pekerja tidaklah sederhana 
terlepas, sehingga klien dapat menggunakan aplikasi ini dengan lancar tanpa takut berpisah dengan pekerja

\section{Keamanan Informasi}

Kantor verifikasi klien digunakan untuk membatasi hak akses klien sesuai kebutuhan klien.

\section{J. MODEL ALIRAN INFORMASI SIMTAP YANG DIKEMBANGKAN}

Model aliran data SIMTAP ini dikaitkan dengan beberapa bagian, yang semuanya terkait dengan kerangka kerja, baik sebagai klien data maupun sebagai pemasok data. Seperti yang terdapat pada Gambar 2. Aliran Data, data dimulai dari help counter yang melayani pendaftaran, angsuran, akomodasi dokumen dan data kemudian ke pusat Administrasi untuk mencatat dokumen-dokumen yang dikumpulkan oleh calon. Setiap latihan / tindakan ini dibatasi oleh penyelenggara SIMTAP dan memberikan data media kepada masyarakat umum untuk mengetahui situasi dengan laporan untuk individu yang mengajukan aplikasi.

Keterangan :

- Garis warna merah penyedia informasi

- Garis putus-putus warna hijau pengguna informasi

\section{K. MODEL ALIRAN PENGGUNA INFORMASI SIMTAP YANG DIKEMBANGKAN}




\section{Gambar 3. Aliran Pengguna Informasi}

Gambar 3 diatas menjelaskan User-user mana saja yang menggunakan informasi SIMTAP, diantaranya :

1. Pusat administrasi

- Financial Area, bertanggung jawab membuat Surat Izin Tempat Usaha (SITU)

- Segmen Pemerintah, bertanggung jawab melayani pengembangan Hibah Pembangunan Struktur (IMB)

- Perbaikan Segmen Organisasi, bertanggung jawab untuk membuat Hibah Administrasi Pembangunan (IUJK), Modern Enlistment Endorsement (TDI), Perjanjian Pendaftaran Organisasi (TDP) dan Deklarasi Pendaftaran Stockroom (TDG)

- Cabang Kegiatan, mendapat tugas membuat Surat Izin Usaha Pertukaran (SIUP).

- Divisi Budidaya Satwa bertanggung jawab atas pembuatan Izin Usaha Hewan Domestik (IUP) dan Izin Usaha Pembinaan Satwa (IUPP).

2. Loket Administrasi terdiri dari 4 loket

- Loket I (Pendaftaran) yang bertugas melihat puncak kebutuhan manajerial calon pendamping, mengembalikan dokumen terpecahpecah calon, memberikan verifikasi penerimaan pencatatan dan membuat laporan pelaksanaan kewajiban kepada penyelenggara melalui sekretaris .

- Loket II (Angsuran) yang bertugas menentukan besarnya tugas calon, mendapatkan angsuran, melakukan persetujuan angsuran, menyelesaikan pembukuan manajerial moneter, menyimpan resi angsuran ke Tempat Penyimpanan Teritorial / Penyimpanan Negara, membuat setiap hari, bulan ke bulan dan laporan keuangan tahunan dan membuat tulisan tentang pelaksanaan fasilitator melalui sekretaris.

- Loket III (Akomodasi), mempunyai tugas untuk menyerahkan dokumen yang telah ditangani dan disahkan oleh otoritas yang disetujui kepada calon, membuat bukti serah terima dokumen, mencatat waktu penyelesaian perizinan dan membuat laporan kepada fasilitator melalui UPT sekretaris.

- Loket IV (Data), bertugas melayani data yang diidentifikasi dengan administrasi publik di Unit Koordinasi Bantuan Kepala Daerah Ogan Komering Ilir.

3. Penyelenggara SIMTAP terdiri dari 4 workstation, yaitu: 
- Workstation yang berhubungan dengan ruang otoritas area OKI, untuk situasi ini BUPATI

- Workstation terkait dengan ruang otoritas yang ditunjuk, untuk situasi ini Pejabat Perwakilan

- Workstation yang berhubungan dengan kantor Sekretaris Daerah

- Workstation yang berhubungan dengan tempat kerja Kepala Kantor

4. Situs data digunakan oleh seluruh penduduk untuk mengetahui data tentang penyelenggaraan SIMTAP.

\section{ARSITEKTUR SISTEM}

Keterangan :

* Garis merah merupakan arus pengembangan SIMTAP yang akan dilakukan

Layanan SIMTAP ini dilengkapi oleh sebuah KIOS Komputer (KIOSK) Informasi untuk memudahkan masyarakat dalam memperoleh informasi tentang syarat-syarat administrasi yang diperlukan untuk mengurus surat izin yang diinginkan.

a. PERANGKAT LUNAK PENDUKUNG 
Ide perbaikan dan kemajuan SIMTAP adalah peredaran informasi yang menyusun atau menyampaikan penanganan informasi, sehingga kebutuhan program menggunakan Connection Data Set Administration Framework (RDBMS) yang dapat menjunjung gagasan tersebut di atas, selain ketergantungannya dalam mengawasi informasi baik dari sisi keamanan. dan sudut dan kapasitas after-deal dalam pergerakan informasi.

Persyaratan program dalam SIMTAP meliputi: Framework Programming, Information Base Programming, Correspondence Programming

- Kerangka Pemrograman: Kerangka Kerja Windows 9x, XP, apache

- Pemrograman basis informasi: SQL/Akses Saya

- Pemrograman Aplikasi: Mic. Visual Penting / Mikrofon. Visual Foxpro

\section{b. MODEL Informasi}

Dalam tahap pengembangan SIMTAP diperlukan suatu sistem dan teknik yang meliputi: pengembangan basis informasi, perubahan kumpulan data

Kumpulan data Fondasi

Landasan kumpulan data SIMTAP dapat memanfaatkan informasi mulai dari SIMTAP saat ini dan diubah kembali ke perbaikan yang harus diselesaikan.

Perubahan kumpulan data

Perubahan kumpulan data dari kumpulan data saat ini di SIMTAP untuk digunakan sebagai mode data untuk dasar kumpulan data yang digunakan oleh situs data. 
Berbagai desain antarmuka SIMTAP di atas memiliki empat menu tab termasuk tab "Beranda", "Data", "Daftar" dan "Masuk". Selanjutnya ada data tentang "Status Hibah" dan sedikit data tentang dasar-dasar perbaikan SIMTAP. Setiap menu ini memiliki submenu seperti yang ditunjukkan pada Gambar 5. Konstruksi progresif antarmuka SIMTAP. Untuk tambahan kehalusan, data pada setiap menu akan diperjelas pada gambar konfigurasi antarmuka menu berikut.

\section{PENGUJIAN Kerangka}

Bagian ini akan menjelaskan tentang pengujian pemrograman SIMTAP, kasus yang dicoba, dan rencana pembuktian dan pengujian yang dapat dikenali. Dalam membina pemograman SIMTAP memanfaatkan bahasa pemograman PHP dan Microsoft Visual Foxpro dengan kumpulan data MySQL-nya. Pengujian pemrograman SIMTAP menggunakan teknik penemuan, yang hanya menyoroti kebutuhan utilitas produk. Dalam percobaan dengan siklus yang sama akan dibahas dengan percobaan interaksi. Tes terdiri dari pengujian persetujuan dan pengujian unit.

Sebelum memimpin pengujian, pembeda bukti apa yang akan dicoba dan rencana pengujian diselesaikan. Hal ini dilakukan agar produk yang dibuat dapat diperkirakan berdasarkan info yang dimasukkan dan hasil normal. Tabel terlampir membedakan halhal yang akan dicoba.

\section{N. KESIMPULAN}

Dengan kemajuan One-Stop The Board Framework, ada beberapa kualitas positif yang diperoleh baik untuk pemerintah daerah OKI, khususnya organisasi yang berwenang di daerah tersebut, sebagai berikut:

1. Memperbaiki Sifat Administrasi Wilayah Setempat

2. Meningkatkan Perhatian Publik dalam Perizinan

3. Meningkatkan Kemampuan Aset Manusia

4. Memperluas Kolaborasi dengan Kantor Terkait

5. Pelaksanaan Otoritatif yang Produktif dan Layak Bertambah 


\section{O. DAFTAR PUSTAKA}

Keinginan, J.D., Wheelen T.L., 1996, "Administrasi Kunci", Organisasi Distribusi Addison Wesley.

Indrajit, E., 2000, "Prolog Ide Dasar Kerangka Data Para Eksekutif dan Inovasi Data", PT. Elex Media Komputindo, Jakarta.

Laudon, Kenneth C. lebih lanjut, Laudon, Jane Cost. Para eksekutif Data Frameworks: Dealing with the Computerized Firm, rilis kedelapan. New Jersey: Koridor Pearson Prentice, 2004

Pressman, R.S., 1997, "Pemrograman komputer", McGraw-Slope Organisations, New York. 